\title{
Bacillus galactosidilyticus sp. nov., an alkali-tolerant $\beta$-galactosidase producer
}

\author{
Correspondence \\ Marc Heyndrickx \\ M.Heyndrickx@clo.fgov.be
}

\author{
Marc Heyndrickx, ${ }^{1}$ Niall A. Logan, ${ }^{2}$ Liesbeth Lebbe, $^{3}$ \\ Marina Rodríguez-Díaz, ${ }^{2}$ Gillian Forsyth, ${ }^{2}$ Johan Goris, ${ }^{3}$ \\ Patsy Scheldeman ${ }^{1}$ and Paul De Vos $^{3}$ \\ 1Department of Animal Product Quality, Center for Agricultural Research-Ghent, \\ Brusselsesteenweg 370, B-9090 Melle, Belgium \\ ${ }^{2}$ School of Biological and Biomedical Sciences, Glasgow Caledonian University, Cowcaddens \\ Road, Glasgow G4 OBA, UK \\ ${ }^{3}$ Vakgroep BFM WE10V, Laboratorium voor Microbiologie, Universiteit Gent, \\ K.L. Ledeganckstraat 35, B-9000 Gent, Belgium
}

Bacillus lentus and Bacillus firmus, which were both described in the 1930s (Werner, 1933; Gibson, 1935) and included in the Approved List of Bacterial Names (Skerman et al., 1980), are two species that have long been recognized as being genetically and phenotypically heterogeneous. Typical strains of both species can readily be differentiated from each other and from other Bacillus species with traditional and API tests, as B. lentus produces acid from a wider range of carbohydrates. DNA homology data suggest that the two species are distinct, but intermediate strains can be allocated to either species (Logan \& Berkeley, 1981; Claus \& Berkeley, 1986). In the first comprehensive phenotypic study of the genus Bacillus that incorporated these species (Gordon et al., 1973), although only three strains of B. lentus (cautiously classified by the authors as unassigned strains) were included, it was already recognized that these few strains of B. firmus and B. lentus may represent a spectrum-like species. Some years later, Gordon et al. (1977) asked the taxonomic question 'Do B. firmus and $B$. lentus represent a series or a species?'. Numerous

Published online ahead of print on 31 October 2003 as DOI 10.1099/ ijs.0.02816-0.

\footnotetext{
Abbreviation: ARDRA, amplified rDNA restriction analysis.

The GenBank/EMBL/DDBJ accession numbers for the 16S rRNA gene sequences of Bacillus galactosidilyticus LMG $17892^{\top}$ and Bacillus sp. R-6760, both determined in this work, are AJ535638 and AJ535639, respectively.

Supplementary figures showing a full phylogenetic tree and normalized computer profiles from SDS-PAGE analysis are available as supplementary material in IJSEM Online.
}

alkaliphilic Bacillus strains have been classified as $B$. firmus, B. lentus (divided into three groups) or ' $B$. firmus$B$. lentus intermediates', the latter group accounting for nearly half of strains investigated (Gordon \& Hyde, 1982). This phenotypic heterogeneity was further demonstrated in a numerical study by Priest et al. (1988), which classified environmental isolates that were related to B. firmus and had been described previously as ' $B$. firmus- $B$. lentus intermediates' in three phenetic clusters. Genetic heterogeneity of the species was demonstrated in several studies. Several DNA homology groups have been described in B. firmus (Fahmy et al., 1985) and, in another study, five B. lentus strains showed low DNA homologies with each other (and with B. firmus) (Seki et al., 1983). The 'complex' of alkaliphilic B. firmus $-B$. lentus intermediate strains, many of which were investigated previously by Gordon \& Hyde (1982), was divided into separate clusters on the basis of genomic DNA G + C content and physiological properties (Fritze et al., 1990). This study suggested the presence of numerous species rather than a 'continuum' of strains, but no further taxonomic studies have been undertaken.

B. lentus is isolated frequently from raw and pasteurized milk. In an elaborate taxonomic study of the aerobic sporeforming flora of raw milk, a novel Bacillus strain (LMG $17892^{\mathrm{T}}$ ) was isolated, which was closely related phylogenetically to B. lentus (Heyndrickx \& Scheldeman, 2002). On the basis of a polyphasic taxonomic study, a close relationship was found between this strain and four other culture collection strains that were labelled originally as B. lentus, B. firmus or Bacillus circulans. As a result, a novel 
species, Bacillus galactosidilyticus sp. nov., is proposed. The proposal of this species is a further step in resolving the taxonomic enigma of the Bacillus lentus-Bacillus firmus complex.

Two novel strains, LMG $17892^{\mathrm{T}}\left(=\mathrm{DSM} 15595^{\mathrm{T}}=\right.$ Logan $\mathrm{B} 2188^{\mathrm{T}}=\mathrm{MB} 800^{\mathrm{T}}$ ) and R-6760, were freshly isolated from raw milk after heat-treatment $\left(10 \mathrm{~min}\right.$ at $80^{\circ} \mathrm{C}$ and $30 \mathrm{~min}$ at $100^{\circ} \mathrm{C}$, respectively) for pasteurization of the sample and activation of spores, plating on brain heart infusion (BHI; Oxoid) supplemented with Bacteriological agar no. 1 ( $15 \mathrm{~g} \mathrm{l}^{-1}$; Oxoid) and filter-sterilized vitamin $\mathrm{B}_{12}$ $\left(1 \mathrm{mg} \mathrm{l}^{-1}\right)$ and incubation at $37^{\circ} \mathrm{C}$ for $48 \mathrm{~h}$. The other culture collection strains included in this study, with their respective isolation sources (if known), were as follows: strain LMG 12353 [ = Logan B0353 = NRRL NRS-769; listed as a B. firmus strain by Gordon et al. (1973)], isolated from partially decomposed wheat grain; $B$. lentus R-15577 (=Logan B0437; Wellcome collection); B. lentus R-16004 (=Logan B0439; Wellcome collection); and B. circulans LMG 12396 (=Logan B0419), isolated from infant bile. The type strains of $B$. lentus $\left(\right.$ LMG $16798^{\mathrm{T}}=\mathrm{NCIMB}$ $\left.8773^{\mathrm{T}}=\operatorname{Logan} \mathrm{B} 0779^{\mathrm{T}}\right)$ and B. circulans $\left(\mathrm{LMG} 13261^{\mathrm{T}}=\right.$ DSM $11^{\mathrm{T}}$ ) and another authentic strain of $B$. lentus $(\mathrm{R}-16003=$ Logan $\mathrm{B} 0436)$ were also included for some analyses. All strains were maintained on trypticase soy agar (TSA) that contained $5 \mathrm{mg} \mathrm{MnSO}_{4} \mathrm{I}^{-1}$ to enhance sporulation, as described by Logan et al. (2000). Amplified rDNA restriction analysis (ARDRA) was performed as described previously (Heyndrickx et al., 1996). Almostcomplete 16S rDNA sequences were obtained for strains LMG $17892^{\mathrm{T}}$ and R-6760, as described by Scheldeman et al. (2002) with the modification that an Applied Biosystems ABI 310 sequencer (Perkin Elmer Applied Biosystems) was used. Sequences were used for phylogenetic analysis with BioNumerics software (Applied Maths) as described by Logan et al. (2002). For determination of DNA G+C content of and DNA-DNA hybridization between strains LMG 17892 ${ }^{\mathrm{T}}$, LMG 12353, LMG 12396, R-6760 and some Bacillus reference strains, approximately $1 \mathrm{~g}$ biomass was harvested from agar plates and DNA was purified as described by Logan et al. (2000) with the following modifications: lysozyme was dissolved in TE buffer with an increased EDTA concentration $(1.21 \mathrm{~g}$ Tris $/ \mathrm{HCl}, 6 \mathrm{ml}$ $0.5 \mathrm{M}$ EDTA; pH 8.0 in 11 MilliQ water) and cell suspensions were incubated with lysozyme until viscosity increased (usually after 10-15 min). The DNA G+C content was determined by HPLC, using further specifications given by Logan et al. (2000). DNA-DNA hybridization was performed by using a modification of the microplate method described by Ezaki et al. (1989), as described by Willems et al. (2001). A hybridization temperature of $37^{\circ} \mathrm{C}$ was used. Cells of strains LMG $17892^{\mathrm{T}}$, LMG 12353, LMG 12396, R-15577, R-16004 and R-6760 were obtained as described by Heyndrickx et al. (1998) and subjected to SDSPAGE analysis of whole-cell proteins, according to Pot et al. (1994). SDS-PAGE data were collected and interpreted as described by Vauterin \& Vauterin (1992). For GC analysis of methylated cellular fatty acids, cells of the same strains were grown and analysed as described by Heyndrickx et al. (1998) and Vauterin et al. (1991). All six strains, as well as the above-mentioned type strains and authentic strains of B. lentus, B. firmus and B. circulans, were characterized phenotypically by the methods of Logan \& Berkeley (1984); other characters were determined and data were analysed numerically as described by Logan et al. (2000).

Comparison of the ARDRA pattern of strains LMG $17892^{\mathrm{T}}$ and R-6760 with those in a database of over 1000 authentic strains of aerobic, endospore-forming bacteria did not yield any identification. On the other hand, >90\% similarity was found between strain LMG $17892^{\mathrm{T}}$ and four strains in the database that did not cluster with the type strain of the respective species to which they were assigned originally, i.e. B. firmus LMG 12353, B. lentus R-15577, B. lentus R-16004 and B. circulans LMG 12396 (data not shown). The ARDRA pattern of strain R-6760 showed $87 \cdot 5 \%$ similarity to that of strain LMG $17892^{\mathrm{T}}$. In 16S rDNA sequence comparisons with entries in GenBank/EMBL, the closest ungapped FASTA matches with a species with a validly published name that were achieved for strain LMG $17892^{\mathrm{T}}$ (1486 bp; accession no. AJ535638) and strain R-6760 (1423 bp; accession no. AJ535639) were $96 \cdot 3$ and $96 \cdot 6 \%$, respectively, with B. lentus (accession no. AB021189). On the other hand, 16S rDNA similarities of $97 \cdot 4$ and $97 \cdot 1 \%$, respectively, were found with an unidentified strain in GenBank/EMBL, TGS137, which was isolated from a composter (accession no. AB020192). Strains LMG $17892^{\mathrm{T}}$ and R-6760 showed $98 \cdot 3 \% 16 \mathrm{~S}$ rDNA sequence similarity to each other. In phylogenetic cluster analysis by using neighbour-joining (Fig. 1), both strains clustered closely together in the radius of the genus Bacillus, with B. lentus and related species as

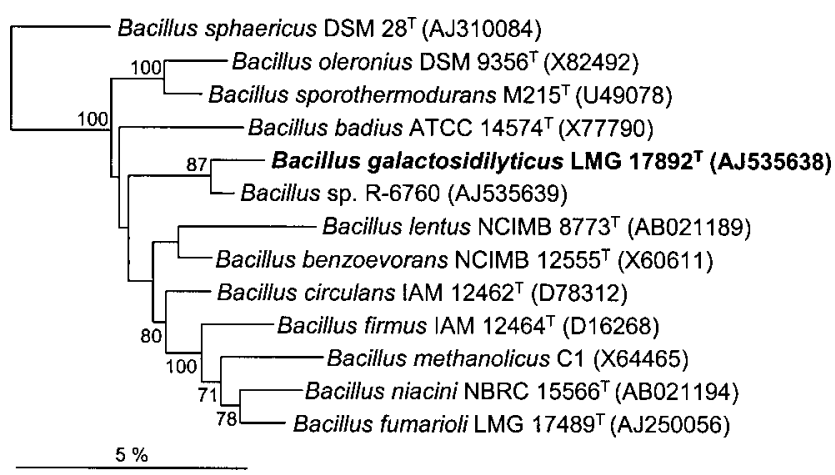

Fig. 1. Neighbour-joining clustering of $16 \mathrm{~S}$ rDNA sequences (rooted with Bacillus sphaericus as reference), based on a selection of $16 \mathrm{~S}$ rDNA sequences of the nearest neighbours to Bacillus galactosidilyticus LMG $17892^{\top}$ and Bacillus sp. R-6760 from GenBank/EMBL (accession numbers are given in parentheses). Only the nearest neighbours are shown here; a more complete tree is given as supplementary material in IJSEM Online. 
the closest phylogenetic relatives (a more complete tree that includes Bacillus subtilis, the type species of the genus Bacillus, is given as supplementary material in IJSEM Online).

From SDS-PAGE analysis, it follows that five strains (LMG $17892^{\mathrm{T}}$, LMG 12396, LMG 12353, R-16004 and R-15577) formed a homogeneous group at a similarity level of $83 \%$, with strain R-6760 linked to this group at $80 \%$ similarity (a figure showing UPGMA clustering of normalized SDSPAGE patterns is given as supplementary material in IJSEM Online).

In API $50 \mathrm{CHB}$ tests (data not shown), the five strains LMG 17892 ${ }^{\mathrm{T}}$, LMG 12396, LMG 12353, R-15577 and R-16004 gave weak and varied reactions and did not present a consistent profile; they showed consistent results in API $20 \mathrm{E}$ tests and in their morphological characters. In numerical analysis of API tests and other phenotypic characters, they clustered together at $88 \% S_{\mathrm{G}}$ and with isolates of Bacillus shackletonii from Candlemas Island (Logan et al., 2004) at $86 \% S_{\mathrm{G}}$. These two groups merged with the group of unreactive strains (containing $B$. firmus) at $86 \% S_{\mathrm{G}}$. Phenotypic characters that distinguish the five above-mentioned strains from the phenotypically related species $B$. shackletonii and from the phylogenetically related species B. lentus are shown in Table 1. Strain R-6760 showed some phenotypic similarity to strains LMG $17892^{\mathrm{T}}$, LMG 12396, LMG 12353, R-15577 and R-16004, but gave much stronger reactions in API $50 \mathrm{CHB}$ tests, did not show any casein hydrolysis and produced very swollen sporangia.

DNA homology values (data not shown) revealed high DNA interrelatedness $(93 \cdot 5-99 \cdot 0 \%)$ within the abovementioned SDS-PAGE group of strains (LMG $17892^{\mathrm{T}}$, LMG 12396, LMG 12353, R-15577 and R-16004), whereas a low DNA homology value $(32 \cdot 5 \%)$ was found between strains LMG $17892^{\mathrm{T}}$ and R-6760. DNA homology values with the type strains of $B$. lentus and $B$. circulans were low $(<30 \%)$.

The genetic and phenotypic data presented above show that strains LMG $17892^{\mathrm{T}}$, LMG 12353, LMG 12396, R-15577 and R-16004 belong to a novel Bacillus species, for which we propose the name Bacillus galactosidilyticus sp. nov. Strain R-6760 represents the core of another novel Bacillus species, of which more strains must be identified before a formal species proposal can be made.

\section{Description of Bacillus galactosidilyticus sp. nov.}

Bacillus galactosidilyticus (ga.lac.to.si.di.ly'ti.cus. N.L. neut. n. galactosidum galactoside; N.L. masc. adj. lyticus lysing, dissolving; N.L. masc. adj. galactosidilyticus referring to a positive ONPG test, revealing $\beta$-galactosidase activity).

Cells are $0 \cdot 7-0.9 \mu \mathrm{m}$ in diameter and $2-5 \mu \mathrm{m}$ in length, motile in a tumbling motion, Gram-positive or -variable, small, plump, round-ended rods that occur singly or in
Table 1. Some characters for distinguishing between $B$. galactosidilyticus, B. shackletonii and B. lentus

Taxa: 1, B. galactosidilyticus; 2, B. shackletonii; 3, B. lentus. Characters are scored as:,$+>85 \%$ positive; $+/ \mathrm{W}$, positive or weakly positive; $\mathrm{V}$, variable (26-74\% positive); -, 0-15\% positive; $\mathrm{W}$, weakly positive reaction.

\begin{tabular}{|lccc|}
\hline Character & $\mathbf{1}$ & $\mathbf{2}^{*}$ & $\mathbf{3}$ \\
\hline Gram staining & + /V & + & + \\
Anaerobic growth & + & + & - \\
Growth at pH 10.5 & + & - & - \\
Casein hydrolysis & $\mathrm{W}$ & + & - \\
Citrate utilization & - & - & $\mathrm{V}$ \\
Urease production & $\mathrm{V}$ & - & + \\
Nitrate reduction & + & - & + \\
Acid from: & & & \\
L-Arabinose & $\mathrm{V}$ & - & - \\
Ribose & $\mathrm{V}$ & - & $+/ \mathrm{W}$ \\
D-Xylose & $\mathrm{V}$ & - & $+/ \mathrm{W}$ \\
L-Xylose & - & - & $+/ \mathrm{W}$ \\
Galactose & $\mathrm{V}$ & - & $+/ \mathrm{W}$ \\
Rhamnose & $\mathrm{V}$ & - & $+/ \mathrm{W}$ \\
Mannitol & - & $\mathrm{W}$ & $+/ \mathrm{W}$ \\
Lactose & $\mathrm{V}$ & - & $+/ \mathrm{W}$ \\
Melibiose & $\mathrm{V}$ & - & $+/ \mathrm{W}$ \\
Sucrose & $\mathrm{V}$ & - & $+/ \mathrm{W}$ \\
D-Melezitose & $\mathrm{V}$ & - & $+/ \mathrm{W}$ \\
D-Raffinose & $\mathrm{V}$ & - & $+/ \mathrm{W}$ \\
Starch & $\mathrm{V}$ & - & $+/ \mathrm{W}$ \\
Gentiobiose & $\mathrm{V}$ & - & $+/ \mathrm{W}$ \\
\hline
\end{tabular}

${ }^{\star}$ Data from Logan et al. (2004).

pairs, and occasionally in short chains. They bear ellipsoidal endospores that lie in central, paracentral and subterminal positions within slightly swollen sporangia (Fig. 2). After 2 days on TSA, colonies are approximately $1 \mathrm{~mm}$ in diameter, smooth, flat and butyrous; their edges are usually irregular with pointed projections that may spread and become rhizoid in old cultures; they are creamy or off-white in colour, with opaque centres. Organisms are facultatively anaerobic and catalase-positive. Growth occurs at 30 and $40{ }^{\circ} \mathrm{C}$, but not at $50{ }^{\circ} \mathrm{C}$. Growth occurs between $\mathrm{pH} 6$ and $10 \cdot 5$, but not at $\mathrm{pH} 5$ or below. Casein hydrolysis is very weak. In API $20 \mathrm{E}$ tests, $o$-nitrophenyl $\beta$-D-galactoside reaction is positive; arginine dihydrolase, lysine decarboxylase and ornithine decarboxylase are negative; citrate is not utilized; hydrogen sulphide is not produced; urease production is variable; Voges-Proskauer reaction is negative; indole is not produced; and gelatin is not hydrolysed. Nitrate is reduced to nitrite. Hydrolysis of aesculin is positive. In the API $50 \mathrm{CHB}$ gallery, acid is produced without gas, often weakly, from $\mathrm{N}$-acetylglucosamine, D-fructose and D-glucose. Acid production from the following carbohydrates is variable and, when positive, is usually very weak: amygdalin, L-arabinose, arbutin, 


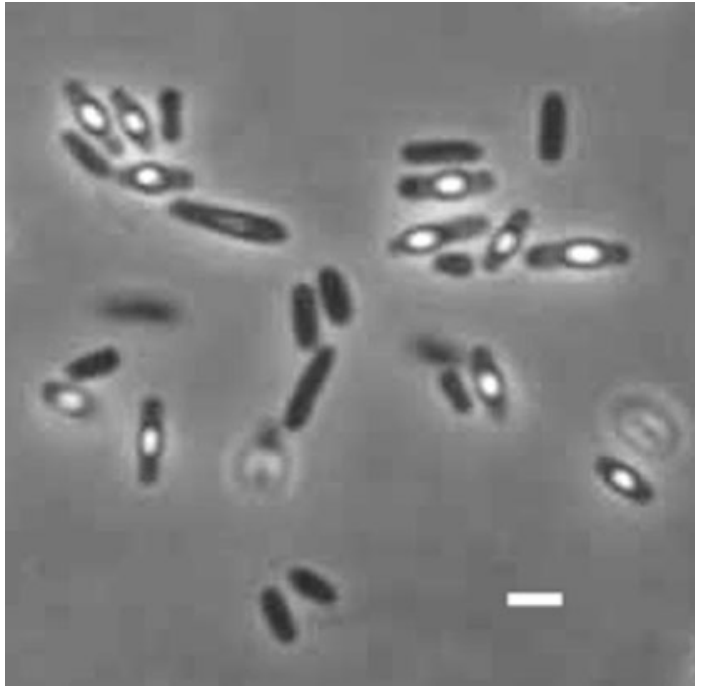

Fig. 2. Photomicrograph of sporangia and vegetative cells of B. galactosidilyticus LMG $17892^{\top}$, viewed by phase-contrast microscopy; ellipsoidal spores lie centrally, paracentrally and subterminally in slightly swollen sporangia. Bar, $2 \mu \mathrm{m}$.

D-cellobiose, galactose, gentiobiose, inulin, lactose, maltose, mannitol, D-mannose, D-melezitose, D-melibiose, methyl D-glucoside, D-raffinose, rhamnose, ribose, salicin, starch, sucrose, D-trehalose, D-turanose and D-xylose. Acid is not produced from the following carbohydrates: adonitol, D-arabinose, D- or L-arabitol, dulcitol, erythritol, D- and L-fucose, glycerol, gluconate, 2-keto-D-gluconate, 5-keto-Dgluconate, glycogen, D-lyxose, methyl D-mannoside, mesoinositol, sorbitol, L-sorbose, D-tagatose, L-xylose, methyl xyloside and xylitol. Major cellular fatty acids (mean percentage $\pm S D$ of total fatty acids) are: $\mathrm{C}_{14: 0}(8 \cdot 32 \pm$ $2 \cdot 51 \%)$, iso- $\mathrm{C}_{15: 0}(12 \cdot 71 \pm 1 \cdot 72 \%)$, anteiso- $\mathrm{C}_{15: 0}(32 \cdot 60 \pm$ $1 \cdot 94 \%)$ and $\mathrm{C}_{16: 0}(27 \cdot 42 \pm 3.04 \%)$. The following fatty acids are present in smaller amounts (mean percentage \pm SD of total fatty acids): iso- $\mathrm{C}_{14: 0}(3 \cdot 96 \pm 0 \cdot 73 \%), \mathrm{C}_{15: 0}$ $(5 \cdot 31 \pm 1 \cdot 08 \%)$, iso-C $\mathrm{C}_{16: 0}(2 \cdot 45 \pm 0 \cdot 44 \%)$ and anteiso$\mathrm{C}_{17: 0}(4 \cdot 49 \pm 0 \cdot 72 \%)$. Trace amounts $(<1 \%$ of total fatty acids) of the fatty acids iso- $\mathrm{C}_{13: 0}$ and iso- $\mathrm{C}_{17: 0}$ are also present. DNA G $+\mathrm{C}$ content is $37.7 \mathrm{~mol} \%$ for the type strain and $35 \cdot 7-38 \cdot 2 \mathrm{~mol} \%$ for other strains.

The type strain is LMG $17892^{\mathrm{T}}\left(=\mathrm{DSM} 15595^{\mathrm{T}}=\mathrm{Logan}\right.$ $\left.\mathrm{B} 2188^{\mathrm{T}}=\mathrm{MB} 800^{\mathrm{T}}\right)$. The $16 \mathrm{~S}$ rRNA gene sequence of the type strain is deposited at GenBank/EMBL under accession no. AJ535638. In the variable characters listed above, the type strain is negative for urease hydrolysis and acid is produced without gas from arbutin, D-cellobiose, D-melibiose, D-melezitose, D-raffinose, starch, sucrose and D-trehalose.

\section{Acknowledgements}

We thank Dr Lieve Herman (Department of Animal Product Quality, Melle, Belgium) for providing us with the raw milk strain
LMG $17892^{\mathrm{T}}$. We are very grateful to Elly Engels for excellent technical assistance. We are most grateful to bioMérieux for providing API materials and for supporting G. F. and M. R.-D.; P. D. V. is indebted to the Fund for Scientific Research - Flanders for personnel and research grant G.0156.02. We thank Professor H. G. Trüper for advising us on nomenclatural etymology.

\section{References}

Claus, D. \& Berkeley, R. C. W. (1986). Genus Bacillus Cohn 1872, $174^{\mathrm{AL}}$. In Bergey's Manual of Systematic Bacteriology, vol. 2, pp. 1105-1139. Edited by P. H. A. Sneath, N. S. Mair, M. E. Sharpe \& J. G. Holt. Baltimore: Williams \& Wilkins.

Ezaki, T., Hashimoto, Y. \& Yabuuchi, E. (1989). Fluorometric deoxyribonucleic acid-deoxyribonucleic acid hybridization in microdilution wells as an alternative to membrane filter hybridization in which radioisotopes are used to determine genetic relatedness among bacterial strains. Int J Syst Bacteriol 39, 224-229.

Fahmy, F., Flossdorf, J. \& Claus, D. (1985). The DNA base composition of the type strains of the genus Bacillus. Syst Appl Microbiol 6, 60-65.

Fritze, D., Flossdorf, J. \& Claus, D. (1990). Taxonomy of alkaliphilic Bacillus strains. Int J Syst Bacteriol 40, 92-97.

Gibson, T. (1935). The urea-decomposing microflora of soils. I. Description and classification of the organisms. Zentbl Bakteriol Parasitenkd Infektkrankh Hyg Abt II 92, 364-380.

Gordon, R. E. \& Hyde, J. L. (1982). The Bacillus firmus-Bacillus lentus complex and $\mathrm{pH} 7 \cdot 0$ variants of some alkalophilic strains. J Gen Microbiol 128, 1109-1116.

Gordon, R. E., Haynes, W. C. \& Pang, C. H.-N. (1973). The genus Bacillus (Agriculture Handbook no. 427). Washington, DC: Agricultural Research Service, United States Department of Agriculture.

Gordon, R. E., Hyde, J. L. \& Moore, J. A., Jr (1977). Bacillus firmusBacillus lentus: a series or one species? Int J Syst Bacteriol 27, 256-262.

Heyndrickx, M. \& Scheldeman, P. (2002). Bacilli associated with spoilage in dairy products and other food. In Applications and Systematics of Bacillus and Relatives, pp. 65-82. Edited by R. C. W. Berkeley, M. Heyndrickx, N. A. Logan \& P. De Vos. Oxford: Blackwell Science.

Heyndrickx, M., Vauterin, L., Vandamme, P., Kersters, K. \& De Vos, P. (1996). Applicability of combined amplified ribosomal DNA restriction analysis (ARDRA) patterns in bacterial phylogeny and taxonomy. J Microbiol Methods 26, 247-259.

Heyndrickx, M., Lebbe, L., Kersters, K., De Vos, P., Forsyth, G. \& Logan, N. A. (1998). Virgibacillus: a new genus to accommodate Bacillus pantothenticus (Proom and Knight 1950). Emended description of Virgibacillus pantothenticus. Int J Syst Bacteriol 48, 99-106.

Logan, N. A. \& Berkeley, R. C. W. (1981). Classification and identification of members of the genus Bacillus using API tests. In The Aerobic Endospore-Forming Bacteria: Classification and Identification, pp. 105-140. Edited by R. C. W. Berkeley \& M. Goodfellow. London: Academic Press.

Logan, N. A. \& Berkeley, R. C. W. (1984). Identification of Bacillus strains using the API system. J Gen Microbiol 130, 1871-1882.

Logan, N. A., Lebbe, L., Hoste, B. \& 7 other authors (2000). Aerobic endospore-forming bacteria from geothermal environments in northern Victoria Land, Antarctica, and Candlemas Island, South Sandwich archipelago, with the proposal of Bacillus fumarioli sp. nov. Int J Syst Evol Microbiol 50, 1741-1753.

Logan, N. A., Forsyth, G., Lebbe, L. \& 8 other authors (2002). Polyphasic identification of Bacillus and Brevibacillus strains from 
clinical, dairy and industrial specimens and proposal of Brevibacillus invocatus sp. nov. Int J Syst Evol Microbiol 52, 953-966.

Logan, N. A., Lebbe, L., Verhelst, A., Goris, J., Forsyth, G., Rodríguez-Díaz, M., Heyndrickx, M. \& De Vos, P. (2004). Bacillus shackletonii sp. nov., from volcanic soil on Candlemas Island, South Sandwich archipelago. Int J Syst Evol Microbiol 54, 373-376.

Pot, B., Vandamme, P. \& Kersters, K. (1994). Analysis of electrophoretic whole-organism protein fingerprints. In Chemical Methods in Bacterial Systematics, pp. 493-521. Edited by M. Goodfellow \& A. G. O'Donnell. Chichester, UK: Wiley.

Priest, F. G., Goodfellow, M. \& Todd, C. (1988). A numerical classification of the genus Bacillus. J Gen Microbiol 134, 1847-1882.

Scheldeman, P., Herman, L., Goris, J., De Vos, P. \& Heyndrickx, M. (2002). Polymerase chain reaction identification of Bacillus sporothermodurans from dairy sources. J Appl Microbiol 92, 983-991.

Seki, T., Minoda, M., Yagi, J. \& Oshima, Y. (1983). Deoxyribonucleic acid reassocation between strains of Bacillus firmus, Bacillus lentus, and intermediate strains. Int J Syst Bacteriol 33, 401-403.
Skerman, V. B. D., McGowan, V. \& Sneath, P. H. A. (1980). Approved lists of bacterial names. Int J Syst Bacteriol 30, 225-420.

Vauterin, L. \& Vauterin, P. (1992). Computer-aided objective comparison of electrophoresis patterns for grouping and identification of microorganisms. Eur Microbiol 1, 37-41.

Vauterin, L., Yang, P., Hoste, B., Vancanneyt, M., Civerolo, E. L., Swings, J. \& Kersters, K. (1991). Differentiation of Xanthomonas campestris pv. citri strains by sodium dodecyl sulfate-polyacrylamide gel electrophoresis of proteins, fatty acid analysis, and DNA-DNA hybridization. Int J Syst Bacteriol 41, 535-542.

Werner, W. (1933). Botanische Beschreibung häufinger am Buttersäureabbau beteiligter sporenbildender Bakterienspezies. Zentbl Bakteriol Parasitenkd Infektkrankh Hyg Abt II 87, 446-475 (in German).

Willems, A., Doignon-Bourcier, F., Goris, J., Coopman, R., de Lajudie, P., De Vos, P. \& Gillis, M. (2001). DNA-DNA hybridization study of Bradyrhizobium strains. Int $J$ Syst Evol Microbiol 51, 1315-1322. 